\title{
Spiritual Process in Lightprayer: A Network of New Religious Practice
}

\author{
ILONA RAUNOLA \\ University of Eastern Finland
}

\begin{abstract}
This article considers the conditions of spiritual process in the new kind of religiousness called Lightprayer. Based on the analysis, it is argued that Lightprayer itself and the practice involved can be seen as a processual approach towards the self and spirituality. It is part of a wider change in religious behaviour. To approach the spiritual process I will draw upon the procedures of actor-network theory (ANT). The ethnographic material, field notes, photographs, and interviews concerning the practices of 'I am' clauses and the 'fire ritual' are interpreted from the perspective of ANT. The perspective of ANT foregrounds the contributions and roles of the human and non-human actors in the actualisation of the spiritual process in Lightprayer. The spiritual process functions as a protocol in Lightprayer and sustains the connections that have been negotiated. However, it also enables the participants to negotiate their individual worldviews. Analysing the interaction within the practices of Lightprayer is essential for an understanding of this new kind of religiousness.
\end{abstract}

Keywords: Lightprayer, spiritual process, Actor-Network theory, interaction, 'I am' clauses, 'fire ritual', new kind of religious practice

In organising events and retreats between 2005 and 2012, Lightprayer was active mainly in Finland and for Finns in Europe. Lightprayer is both the title of the activity and a kind of non-verbal prayer that the leaders Helena and Michael Blanka performed with the participants (Raunola 2010, 290-91). Until 2012 the Blankas lived as a Finnish-German married couple in Germany. ${ }^{1}$ Lightprayer was a combination of ideas rooted in Christianity with Mary as a central character (see Raunola 2017), esoteric New Age and Indian religions, and the dietary particularity of living on light. According to Lightprayer the aim was to help participants to become open to their inner selves, to Light, and to silence.

1 Since relocating to Finland in 2013 the Blankas have launched two separate working arenas. Both continue to work with the teachings of Sri Kaleshwar. 
stillness speaks more clear than words

drumming and lightprayer - experience of the inner stillness and light we will start with the drummingmeditation and go on it as silent lightprayer (LP4)

This article presents Lightprayer from the perspective of the spiritual process that is assumed to take place during retreats. The concept of spiritual process is here a functional concept born of the research material itself. The concept helps to approach the function of Lightprayer and the significance of the retreats.

I consider aspects that contribute to the actualisation of the spiritual process from the perspective of actor-network theory, made famous by sociologist Bruno Latour (Latour 2005). Actor-network theory (ANT) reading enables the observation of complex group interaction between people and things (Callon 1986, Law 1992). Reading through ANT reveals multiple human and non-human actors in the retreats and in practices therein: in addition to the organisers and participants, the venue of the retreat, textual material, instruments, and other actors also enable the spiritual process, not excluding experienced or assumed spiritual actors such as Light.

As Mika Lassander points out, 'ANT can be a fruitful approach for studying beliefs and worldviews in those Western societies that are experiencing relatively rapid changes in their religious landscapes' (Lassander 2012, 239). Lightprayer is one example of this change. ${ }^{2}$ The notion of spiritual process would seem to emphasise the importance of the individual experience in a new kind of religiousness. Lassander illustrates the change with the concepts of mould and trellis. Whereas a mould provides security and norms for behaviour and belief, a trellis enables orientation towards self-expression and individuality (Lassander 2014, 153-6).

What role does the practice of spiritual process play in Lightprayer and for the participants? This article concerns the interactions in the practice of spiritual process during retreats both as an individual experience and as manifested in the material surroundings of the retreat. The anthropological research material guides the reading of the interaction with examples from interviews, field notes, and other research material.

2 The exact definition of the shorthand 'new' religiosity is beyond the scope of this article. 'New' compared to what is the obvious question to be discussed. The emphasis of this article lies in the interaction amongst actors in a particular instance in the field of new religion. It might well turn out that studying the networks of the 'old' religion will yield equally complex and surprising results. 
I will first explicate my theoretical and methodological underpinnings. I will then give an overview of the spiritual process as a religious way of tying entities (Latour 2005, 239). Next I will proceed by presenting an interpretive reading of the research material regarding the exercise of the ' $\mathrm{I}$ am' clauses as an example of individual process. Clauses are given as a black box, i.e. as something that is not explained but nonetheless something that the participant can open (see Table 1).

In the fifth part of the article I will analyse the 'fire ritual' as a special kind of practice and place, a centre of calculation, for the spiritual process to happen. In the last part I will concentrate on a fire ritual at an Assisi retreat as an example of a place for individual negotiations and the shaping of understanding.

\section{Material}

I conducted ethnographic fieldwork between 2008 and 2009 by participating in five retreats and several evening events. Retreats and evenings can be regarded as the most essential forms of Lightprayer work. My approach is that of a participating researcher. Dialogical positioning and ethical fieldwork require intuition and vigilance on the part of the researcher (Raunola 2010). The retreats in question were held in Assisi (Italy), Airisto (Finland), Schwangau (Germany), and Uusi Valamo (New Valamo Orthodox Monastery in Heinävesi, Finland). In addition to the interviews with the participants and the Blankas, the research material consists of numerous photographs and comprehensive field notes. I will also draw on material published on the Lightprayer website (maintained in English, Finnish, and German) and the blog entries written by Helena Blanka in Finnish.

I have changed the names of the interviewees to maintain their anonymity. Pseudonyms have been selected from the Finnish name-day calendar around the times of the retreats.

\section{The interpretive frame of the actor-network theory}

Actor-network theory is also called the sociology of translations (Latour 2005, 106, Callon 1986, 1 Law 1992, 1). Latour's idea of sociology can be summarised as follows: 'Society is not what holds us together but what is held together' (Latour 1986, 276). For Latour the social is dual and problematic in nature. Instead of providing sharply delineated definitions, Latour considers the social as a peculiar movement of reassociation and reassembling (Latour 2005, 7). 
As Lassander describes, an actor network is a 'process-oriented view, focusing on translation as the process in which actors construct meanings and definitions [--] in the pursuit of individual and collective goals' (Lassander 2014, 27). An actor is not the source of an action, but what is made to act by many others (Latour 2005, 46). Creative action is both required and instantiated by change.

For Latour neither society nor social ties exist, but translations between mediators that may generate traceable associations (Latour 2005, 108). In contrast to mediators intermediaries transport meaning without transformation (ibid. 39). Latour adds that when actors are treated as mediators instead of intermediaries, they render the movement of the social visible to the reader (ibid. 128). Reading through ANT helps to explicate the interaction between the actors, while anthropological interpretation seeks the associations linked to the subject matter itself.

The social in the Lightprayer network is movement in the individual and between the individual and the Light, the quasi-object (see table 2). For Latour quasi-objects belong to nature and society only insofar as they are subjects. Quasi-objects are the attachment points of human categories (Latour 2006, 89, 108). According to Lassander the quasi-object seems to be immutable and appears unproblematically as an object (Lassander 2014, 29). Lightprayer events and retreats in particular are centres of calculation where participants and the Blankas meet. Latour describes them as landmarks, as the star-like shape of an oligopticon, ${ }^{3}$ where literal calculations are made possible. From the oligopticon it is possible to see narrow views of the (connected) whole, as long as connections hold (Latour 2005, 178, 181).

In the Lightprayer material, each participant comprises an actor network of her own. These micro- actor-networks relate to the macro-actor network of Lightprayer and become visible in the research material (see Callon \& Latour 1981, 279). The micro and macro-networks connect to each other and interpenetrate.

\section{Spiritual process - a protocol in Lightprayer}

This is Helena Blanka's description of the process on the Lightprayer website:

Lightprayer starts in you a process of opening and becoming more whole. What kind of process - it depends on Your situation now here, on Your

3 cf. Michel Foucault's panopticon (see Latour 2005, 181). 
highest will. Your inner power wakes up and becomes stronger and You by yourself begin to help you. The process may go on several weeks, may be longer. You choose, You want, You choose, what you want during the lightprayer and how to go on then later after it. Lightprayer listens our will. (LP 3)

In the retreats the practice of lightprayer seeks to activate the participant through drumming and spiritual exercises. These initiate the loosely-defined spiritual process described above by Helena Blanka. In the description the spiritual process is considered to happen between 'you' the participant and the 'higher self', while the higher self is connected to Light. According to my interpretation the communication of Light is to take place as the inner knowledge and experience of the participant. The Light is approached with a question and it will answer in individual ways. This I call the agency of Light.

The 'higher self' and 'you' are presented to the participants as a black box. 'A black box contains that which no longer needs to be reconsidered, those things whose contents have become a matter of indifference' (Callon \& Latour 1981, 277). What 'being whole' or, inversely, being incomplete in fact mean remains undefined.

In the quotation the self as a combination of deep and surface levels chooses how to go on with the process. Lightprayer is considered to listen; nothing happens that the subject of the spiritual process does not want. However, the participant is not able to consciously control the process, and the aspects and themes the process raises cannot be premeditated.

When someone has signed up for a retreat, Helena sends general information prior to the event and a specific request for spiritual preparation.

\section{CAN YOU ALREADY HEAR YOUR QUESTION...?}

our retreat is a process, a journey [--] we want it to be for you and for all of us a journey for opening and growing together and journey of the touch of deep light, journey that continues long after our retreat. and we want and ask love and compassion and joy and all the best to your journey! (Email HB 18.4.2008)

The process is consciously activated with the question. In describing the retreat as a process in itself, Helena Blanka utilises the cognitive metaphor LIFE IS A JOURNEY (Lakoff \& Turner 1989, 9), famously expressed by Ralph Waldo Emerson (1803-1882): 'Life is a journey, not a destination.' This emphasises the connotations of a journey towards oneself and the unexpectedness it involves. 
The metaphor 'life is a journey' is parallel to the notion of the spiritual process and symbolises it (see Figure 1). A spiritual process can then be considered as a protocol and a religious way to associate and tie entities together (Latour 2005, 239). According to Latour religion is about gathering entities and creating new associations between non-social elements in a certain way, much as law or science do in their own way (ibid. 239). The spiritual process can be understood as a kind of protocol that Latour suggests, as actors communicating with each other. For Lassander the religious is an outcome of the network instead of a negotiation about the connections. Lassander suggests that ANT reading illuminates 'what people do with religions and what religions do for them' (Lassander 2014, 149, 153). In the case of Lightprayer it is about both aspects. On the one hand, the spiritual process is a religious way to communicate a certain protocol that the actors use to connect to each other and negotiate the connection. On the other, Lightprayer is an outcome of these negotiations.

Helena Blanka's email continues:

[--] asking activates an important natural law. [--] we must ask to receive. by asking we call it into our life - it and answers how... or whatever we have asked. [--] the questions helps us to stay aware. aware even as we fall. for already rising up the journey continues. [--] (Email HB April 18, 2008.)

Helena defines awareness as a means of understanding oneself and one's present situation in life. Thus, the spiritual process and journey could be understood as a change within or in the conditions of life to learn and gain understanding. The reference to the possibility of falling is conspicuous: problem or discontinuity is here contrasted with being whole. Nonetheless, falling is also considered to be part of the process.

The preliminary questions need not be conscious. However, the Blankas want the participants to reflect on why they wish to take part in the retreat and what they expect from it. Arja has participated in Lightprayer for a while and has formulated a definite question for her second retreat in Airisto.

IR: Did you prepare somehow for this retreat? Or did you feel that you'd already waited for this for a long time?

Arja: Of course, you had to think about those questions and wishes, so there was that, but I did not manage to do a lot or didn't have time otherwise. But of course, I have thought about what I wish for and things like that.

IR: Is the question or wish that you probably sent earlier the basis here? 
Arja: Yeah.

IR: Are you conscious of it?

Arja: Well it does pop into mind sometimes but I don't like to think about it all the time.

IR: If you wish to say it, go ahead, but you don't have to. (Chuckle)

Arja: Well this is precisely what I was telling you earlier, about opening up and when you know there is like the other side but there are only kind of flickers from it. You would like to see and feel and hear more about it.

IR: And the one thing here is then like the strengthening of that?

Arja: Right, right, yeah. And of course, some of these more concrete wishes about personal life. But well perhaps this was the biggest of all, to be able to hear oneself better (September 28, 2008).

In Arja's case becoming more open involves the strengthening of the translation between 'you' and a 'higher self'. Arja thinks this would help her to sense 'the other side', the Light, which is present all the time. This is also part of the request to strengthen the protocol, and being involved in Lightprayer.

Peppi describes the process as a more comprehensive part of life, of which the retreat is part.

Peppi: But like I've been there [Orthodox service] for an hour and a half every morning and evening. It has like somehow supported the cleansing. It has been like a journey to the world of Orthodox faith, into the song brought about by the voice that resonates in the body and into the prayer. And then after that the joint sessions of lightprayer that have somehow been taken really deeply and brought about many mental images. And both days I also had personal lightprayers so that this has joined and crystallised into a big process in me that lives in a way. [--]

IR: What made you come to this retreat?

Peppi: I don't know, divine providence, something. [I]t is guidance, a leading light in life. It feels somehow that a circle closes in life that began like a year ago, so now it feels like one journey has all but come to an end or is coming to an end. [--] There has been a kind of a theme, [--] somehow first there was gratitude that I'm here. Then came humility, immense humility. Then came joy. Something like that and a certainty. [--] But every day has had like a theme of its own that arose by itself. And it has too in a way gone along in this. This has been a marvellous experience (April 1, 2009). 
The retreat at Valamo was exceptional in the sense that it took place in surroundings provided by the Orthodox monastery, but was not organised by the institution. For most of the retreat Michael was the sole leader, as Helena had to leave for family reasons after the first day (notes March 29, 2009).

Peppi invokes the metaphor of a journey and describes her process as a combination of the Orthodox services and Lightprayer. She also describes how the process arises from within, as do the themes or phases of the process: gratitude, humility, joy, and certainty. The Orthodox services, song, and prayer become actors in addition to Lightprayer. For example, both services and lightprayers are mediators that activate Peppi's process. Peppi does not define what she means by cleansing, her experience suggests it might concern emotions and memories. The positive emotional work is the outcome of successful translation and the spiritual process.

For Peppi the spiritual process is formed in a bodily manner by the Orthodox services and the communal and individual acts of lightprayer. She describes her experience as 'depth', as if travelling to her soul and bringing back evocations to be consciously processed. J. Gordon Melton states that the New Agers have found affinity with the shaman traditions. The shaman is a mystic communicating in interconnection with nature, who goes off into the wilderness to seek a vision if needed, returning to the everyday of the community (Melton 1990, 409). In Lightprayer the participants are seen to go into the wilderness of their inner experience. The Blankas act as spiritual mentors, guides, and supervisors. During the retreats the spiritual process usually takes the place of guidance. In this case there are practically no directions: each participant follows her own guidance. Yet the Lightprayer and Orthodox surroundings remain to serve as the centres of calculation for the event.

The examples of Arja and Peppi illustrate a successful negotiation of connection, in which Helena Blanka's letter is taken as given and 'you' and 'higher self' as normative. The acceptance of these black boxes creates the grounding for the notion of spiritual process that in turn upholds the network of Lightprayer. As a result, the spiritual process is also, apart from being an experiential feature of the retreats and communication with Light, a protocol that is used to strengthen the sense of connection to Lightprayer.

\section{'I am' clauses - opening the black box}

In what follows I will analyse the exercise of 'I am' clauses as an example of the practice of spiritual process. The clauses have found their way into 
Lightprayer through Jukka Hirvonsalo, a cooperative spiritual teacher of the Blankas at some of the events. Helena has been using these clauses occasionally at some retreats, for example, the New Year retreat. According to Helena in the order she uses them they are connected to the chakra system from one to seven, ${ }^{4}$ roots to the top so that 'true vine' equals the first chakra, as advised by Hirvonsalo (HB December 31, 2008). The idea of the clauses is to programme the mind with the help of breathing.

\author{
keep your eyes closed \\ concentrate on your breathing \\ breath deep peacefully in and out \\ breath in: I am love \\ and out: the one that I am \\ I am love, the one that I am
}

Let this love fill each of your souls

your whole beings

let it flow through you out of your aura into the world, everywhere

now breath in

I am the true vine [John 15:1]

And out: the one that I am

I am, the true vine, the one that I am

I am the way, and the truth, and the life, the one that I am [John 14:6]

I am the door, the one that I am [John 10:9]

I am the bread of life [John 6:35]

I am the good shepherd [John 10:11]

I am the resurrection and the life [John 11:25]

Drumming follows. (Field recording December 31, 2008)

The Blankas present the exercise as a black box, i.e. something that is supposed to be taken as given. Clauses are intermediaries and not explained; instead, each participant is instructed to listen to her or himself about what the clauses mean. However, in the case presented below the black box is opened and applied by Leea. When opened, the black box is activated and

4 One sentence is missing from this practice, the 'I am the light of the world' for the sixth chakra. 
becomes a network itself: the intermediary becomes mediator. Opening reveals the interaction within and enables an analysis of the translation.

Leea has previously mentioned 'I am' clauses and compared them to mantras because of their repetitive nature. She has also said that she repeats the clauses during the retreat.

IR: [--] and what about these, you mentioned them already briefly, the clauses, the 'I am' clauses, mantra-type, what did it accomplish, did it have an effect on you? [--]

Leea: Well I experienced them and I thought they were good. I don't really know if they stirred anything big in me, but I notice that I've kind of begun repeating them more generally. And for instance, when we have been out there in nature and when I was alone on Tegelberg and had those terrible fears that were so shocking, whew. So then I tried to kind of repeat them to make myself calm down.

[--] I go on for a little while, I am panicking as I go. I just leaned on the rock and thought that I won't look at the, that I imagined every time that I would just roll down off the ledge. (Laughter.) Then I went to the safe spot of sorts and then I thought that this is really like an exercise in being present, really concrete. I tried to calm down. I figured that I have nothing to fear now, that I'm completely safe. But I was all the time, I couldn't be in that moment because I kept thinking that I have to go through that terrible journey again on the way back. [--] Because I was alone in there. There was nobody anywhere around to save me. (Laughter). That's how it was, I was just trying, breathing in love and peace and I am love. And then I composed myself and went another two metres forward. This second mountain trip to Tegelberg was a pretty powerful process (Laughter) (January 4, 2009).

When the black box is opened and used in this case, the most essential actors become the mountain, the emotions, and the clauses as scenery in which the spiritual process occurs. Leea considers the clause 'I am love' ${ }^{5}$ to be particularly helpful in soothing fear. The clause acts for the interviewee as a mediator that is involved in the formation of inner knowledge, the 'higher self'. The clause was not connected to any particular chakra in Hirvonsalo's guidelines. Instead, it refers to a holistic conception of the relationship between 'you' and the 'higher self'. In the exercise led by Helena Blanka the

5 The verbatim phrase is not found in the Bible. John presents similar passages about love such as 'that the love with which you have loved me may be in them, and I in them' (John 17:26). In Lightprayer "I am love" is used to tune one's awareness and to the state of love. 
'I am love, the one that I am' clause brings together love and God's wellknown self-designation: 'I am who I am' (Exodus 3:14).

For Leea the process appears as emotional an undertaking as it was for Peppi. The Light agency offers an inner solution in the fear situation. Interestingly, Leea also utilises the concept of journey when describing the way back from the top. In this case the journey is comparable to the metaphor and spiritual process, which is not always pleasant: the emotions vary.

IR: So, in what context have they have been, or what do they mean in Christian belief?

Leea: Well I just think that, they are, they are like the bread of life, it is like all that is. Like what the light perhaps also is. I would think that they aim at just the experience of the divine and its opening in oneself. And I in fact wrote them [the clauses] down in my diary, so I think I would like to begin saying them. But at the same time I noticed that this is the kind of thing, for example, that I would not want to tell to my mother, because she would think that I now imagine myself as some kind of Jesus.

IR: Mocking Jesus.

Leea: Yes, she would see it in a very negative way. Or that is how I imagine her reaction. I can't say that she would take it this way (January 4, 2009).

Climbing the mountain demonstrates the processual work and the interactive aspects that become present and significant in this instance (see Figure 2). Christian beliefs are actors, as is the mountain climber and the diary. The diary replaced the mountain and became the mediator in the individual process and the experience of the significance of the clauses after the retreat. Leea thinks that both the clauses and the Light make the experience of divinity and opening oneself to it possible. The example also shows the change in religious behaviour. Leea's way of belief, reminiscent of Lassander's concept of the trellis, where clauses from the Bible can be newly interpreted, is seen in juxtaposition with her mother's more traditional way. Leea's opening of the black box gives us an idea of what she does with religion and what religion does for her (see Lassander 2014, 149).

A couple of days after the retreat I sent a list of 'I am' clauses to some participants who had requested them. I took the opportunity to ask about the jewellery they wore. This is Leea's answer:

My necklace is made of mountain crystal. I got it before Christmas, and I just felt like taking it with me on the trip. I wore it only a little at the retreat. The 
little rose quartz heart was hanging on my neck more. The bracelet on my wrist is chakra jewellery, there's a rock for every chakra. I perform a couple of chakra meditations with it on car trips. I wear it on my wrist every once in a while. I am particularly delighted about my guardian angel pendant I bought in Füssen. I have worn it ever since! (Email 19.1.2009).

In Leea's worldview the pendants, 'I am' clauses, and the chakra necklace have an effect on her energy system. We visited Füssen on the last day of the retreat. It is easy to surmise that the mountain climb the day before and the emotions experienced in it had something to do with the decision to buy the jewellery. The guardian angel is universally considered to have the function of purveying shelter and guidance. The necklace assumed a role in the interviewee's everyday, and perhaps is a material reminder of the retreat process and hence serves as a mediator, like the 'I am' clauses themselves.

\section{Fire ritual - centres of calculation}

Since 2007 the fire ritual has increasingly taken place at the retreats. Michael Blanka was instrumental in bringing the use of fire to the Lightprayer's spiritual practice. Michael had participated in a fire puja ceremony led by his Hindu teacher guru Sri Kaleshwar (1973-2012) before meeting Helena and had been impressed by its power (email January 20, 2015). Puja means 'worship' and 'divination' in the Hindu tradition, and the rituals are many and varied and typically demand the presence of a priest (Dwivedi 2004, 171f.). The fire ritual of Lightprayer was strongly linked to and reinforced by the puja of Kaleshwar. In the absence of an explicated divinity (Hindu or otherwise) the fire ritual in Lightprayer became a ceremony aimed at the personal and communal spiritual process.

As mentioned earlier, I consider retreats as well as the fire ritual (which is often included in a retreat) as centres of calculation. According to Lassander and Ingman the connections remain as long as the actor network maintains its activity. The centres of calculation not only connect with other sites, but also 'structure the connected whole by translating it'. Lassander and Ingman continue that the translations that are performed at these sites are innovations of the reactions of other actants to the materials circulated through the site (Lassander \& Ingman 2012, 215). Retreats and fire rituals are thus places where human and non-human entities gather together and maintain the connections of Lightprayer, particularly through the practice of the spiritual process. 
At the New Year's retreat in Schwangau the fire ritual was a special event. It was organised outdoors during the night of New Year's Eve near the Blanka's home, which served as the retreat's venue (see Figure 3). With torches and headlamps, the participants carried the sleighs, firewood and other paraphernalia from the car to the snowless beach along a narrow path.

At about 00:30 we had gathered our things and put the bonfire out. Some went ahead when Michael smelled the coconut. He had put a small coconut into the fire. It looked like a big cone in the incandescent fire. Michael told us that it possessed a large amount of energy. I remember on some [previous] retreat that Michael told us about a person who had performed a ritual with a coconut and how the coconut had finally exploded. We should have stayed for a while for the same thing to happen to Michael's coconut (Notes January 1, 2009).

Here the fire ritual as a centre of calculation illustrates the flexibility of the ritual in accommodating various situations. Here it becomes a grand event of the New Year. It also emphasises Michael Blanka's role as an exemplar for participants. Figure 4 illustrates the act of translation (fire ritual) between the mediators of fire and Michael Blanka. The coconut is the material index of the translation. The presence of the mediator's coconut suggests a connection to the Indian religious tradition. However, in Lightprayer the fire ritual changes according to the situation and cultural context. From the perspective of ANT this is an example of the way in which religious content is negotiated collectively in interaction between actors in the centre of calculation.

The fire ritual is typically performed as part of the Lightprayer session. The ritual lasts between one and two hours. The preparations for the fire ritual begin in the morning as Helena Blanka informs the participants that the ritual will take place later the same day. The participants wander in the nearby nature and gather something to burn, such as a branch, leaf, or cone. The mediating substance to be burnt - such as the coconut - is instilled with one's own will. The participant may carry the notion with her the whole day before it is put on the fire. During the fire ritual each participant puts her object and issue on the fire. Helena Blanka describes the way in which the group and the ritual bring together the power to accomplish that what is wished for, typically, letting go or receiving. At the same time, Helena refers to the fire puja:

[--] So until now the fire ritual has been a means of creation for us, so we create with it what we want. I'm not sure what we are going to do with it 
today. Today it has had to be empty, bare, clean, until now. Until I say at the end of the lightprayer what we are going to put onto it. And where do we now focus our attention, what do we concentrate on, what do we create (Field recording September 28, 2008).

The quotation from the Airisto retreat illustrates the flexibility and contextual mutability of Lightprayer. Helena waits for inner guidance, Light agency, and delivers the theme for the fire ritual only having received it in the present moment. Helena is the leading actor of both the fire ritual and the retreat, and can be characterised as the administrator of the centre of calculation of the fire ritual. She receives the information and spreads it further.

A few days later, at the same Airisto retreat, a fire ritual was dedicated to forgiving.

IR: How about these others, for example the fire rituals [--], have any of those felt particularly close to you?

Saila: [A]nd then these fire rituals, well, they are indeed immensely kind of impressive. As in somehow doing things in concrete terms. Like today the forgiving.

IR: Yes and it became, we've done it twice in a way. Was it the thing you put into the fire that occurred or something different?

Saila: Yes, it was the same thing for me. I felt it so strongly then the first time that the next night, not in a dream but in this kind of, I suppose it was a bit like a meditative state, one of these people appeared. I got to experience something I experienced as a little girl that she caused me, well, by being unjust that is, I got to the emotion, grasped it. The child that I was there was in such huge despair. Yes, it appeared like, I haven't thought of that person for ages, I suppose that it was kind of raised then.

IR: Did you experience the forgiving also or?

Saila: Yes. The forgiving is based on understanding that we have in a way made peace. Most of all because I have the mother relationship, or perhaps I have most to forgive to my mother. The previous child in our family, a year-and-a-half before I was born, she drowned as a four-and-a-half-yearold. [--] So I have understood it in a way that we have made the agreement, it must be very difficult to fulfil such an agreement when you are the mother of that child, that you would want to love, but you have agreed, when it has wanted, her soul has wanted for her to treat me this way. 
IR: Have you had similar processes on other retreats? That you go through some emotions or life situations?

Saila: Yes, but perhaps here the most for some reason (October 3, 2008).

In this translation the material and individual aspects, as well as the Light agency of the fire ritual, are interconnected. The fire ritual elicits a dreamt actor network in which the retreat building, the ritual, the place of sleep, the mother, the deceased sibling, souls and agreements amongst them, water, the recalled living infant, despair, sorrow, and forgiveness all create a meeting ground for the past and present. The perspective of ANT facilitates focusing on the emotions and the experience specified by Saila: the despair of a child and the mother's perspective, and the events made understandable through forgiveness. ${ }^{6}$

Fire rituals and retreats in general can be considered venues in which knowledge production builds on the accumulation of resources through circulatory movements to other places, as the various places and events in Saila's account demonstrate (see also Jöns 2011, 1). As Latour puts it, the mobilisations are 'the true heart' of the networks. It is more important to interpret them than facts or mechanisms (Latour 1987, 240f.). In the concrete action of fire ritual the ephemeral actors of the spiritual domain provisionally become observable actors in the network of Lightprayer. At the same time, the idea of the fire ritual as part of the spiritual process strengthens the significance of the centre of calculation.

The examples of Michael Blanka and Saila demonstrate the kind of things the fire rituals as centres of calculation gather together. The rituals are organised to facilitate the spiritual process and the protocol involved. In Lightprayer the fire ritual has become thematically specified: forgiving, for instance. The emotional work has thus become more organised. The centres of calculation not only bring together different kinds of actors; they also provide a physical exercise for the gathering.

\section{Fire of Assisi - a case of negotiation}

The preparations begin on the first day of the retreat after arriving at the house. Where ANT is concerned, the fire ritual and its preparations involve various kinds of agency. The house is damp and bleak, yet it is equipped

6 In another piece of research an interviewee reported having prayed on behalf of his child who died as a grown-up and having received a reassuring and comforting answer from the deceased in a dream (Raunola 2012, 160). 
with a fireplace. Lyydia and another participant, Lilja, developed a personal bond because of Lyydia's sore back that Lilja healed with her hands. In turn Lyydia wanted to prepare the firewood for Lilja. The Blankas had brought firewood for two fires and possible fire rituals, but firewood was not otherwise provided in the house and twigs and kindling were not easily found in the surroundings either. Lyydia had found a dried cypress branch that she was cutting for Lilja and described it as 'an artistic performance'. The cut and dried wood was used to make the communal fire, against Lyydia's aims.

IR: But, well, what are your thoughts so far of this retreat?

Lyydia: [A]nd then as for myself and my own process, for example the fire ritual last night did cause pretty powerful, powerful conflict that I noticed in the evening too, but I just wondered what's going on. [--] It's very, very interesting that my own personal process beginning from this firewood and logs thing went completely differently than I had thought with the wood I had brought that was part of a particular kind of process that has begun and was perhaps an artistic performance and had to do with Lilja this treatment that she gives to my back and so on. And still there's this will thing that I had, that I put into the fire was that I want to hold on. No, I want to stay on the path. And I just happened to give in, or I agreed to leave my own path because Helena had another idea about what was going on. [--] This is just an example of how in the middle of this being together and the whole structure I feel that I go through very important personal issues (May 21, 2008).

Lyydia reflects on her own actions and feels that she has acted against herself by delivering her firewood for general use. Here the intermediary - the firewood - became a mediator. This translation turned out to be significant for her and she worked on it throughout the retreat by means of several fire rituals. On the one hand, Lyydia did not want to let go; on the other, she wanted to please Helena. This was for her also part of a bigger question about what Lightprayer is and why she wants to be part of it. Once again the cognitive metaphor 'life is a journey' is evoked by a participant, this time to describe Lyydia's own will. Stepping off her path was agreeing with Helena. At the end of the interview Lyydia stated that in subsequent fire rituals she aims to remain more firmly on her own path.

The fire ritual held after the interview on the same day (May 21, 2008) was particularly expressive, loud, and constantly changing (see Figure 5). 
The fire isn't burning well.

Erkki thinks that the logs are too big.

Helena comments that they need to bring an axe and a saw with them next time.

Lyydia suggests that each of us should try to make the fire burn better while taking one's thing to burn, as a part of the ritual.

Now the fire is burning again, but Erkki wants to arrange the logs and returns in front of the fireplace for a moment.

Lyydia sits down in front of the fireplace and blows on the fire before setting her branch there. The others are watching quietly, until they start to laugh after Lyydia blows on the fire again and starts to bark like a dog and make other noises before taking her seat. Performance? [--]

Erkki rises to help the fire. Michael goes to upstairs to get the last logs.

Lilja says: 'This fire has a different character (than last night). It doesn't crackle happily, but smoulders and burns in turns.'

Michael brings the rest of the logs and a small hairdryer (for the fire).

Everyone is laughing.

Lilja goes to put branches on the fire. Some of them are still wet. They were collected near the house.

It makes me want to laugh when Lilja is blowing on the fire trying to make it burn. Michael plugs the hairdryer into the extension cable.

[--

Lyydia moves the candles away from the front.

Rebekka whispers: 'I want to make my wish before it's too late.' She rises from her place, takes a handful of leaves to the fire and returns quickly to her place. The wood leans and is about to fall on the floor. Lyydia: 'What a lovely play.'

Everyone is silent and watches the fire (Notes May 21, 2008).

The fire ritual performed by a group signifies individual things to each participant. Putting the will into the fire, however, creates a communal and negotiated state of process. Finally, in the communal fire ritual the element of fire is the dominant actor and the participants relate themselves to it. However, Lyydia is an active agent throughout the ritual and exhibits a certain intensity towards her own process by applying herself to the way in which the fire burns. Eventually, she brings wood from her room to dry, and says aloud that it is not to be burnt yet (see Figure 6).

There is a dramatic quality in this fire ritual 'play', as Lyydia puts it. The whole group improvises to keep the fire going and performs the ritual more 
or less towards Lyydia. At the New Year retreat the fire ritual, however, constituted a specific performance organised in advance by the Blankas. The participants felt no need to alter it.

The last fire ritual was held outside (May 22, 2008). I did not take notes on Lyydia's activity but summarised the balanced atmosphere during the last phase of the retreat in which the fire ritual was essential. One of the participants had named the retreat 'the Fire Retreat' in the afternoon.

In an interview with Lyydia, conducted four months later, we returned to the firewood process. Angels are to be added to the list of actors; these were discussed on the last few nights of the retreat. The interviewee continues talking about remembering her own childhood angel prayer and considers that it became a continuation and endpoint to the firewood episode as part of her spiritual process. The interviewee feels that after the first fire ritual, with other participants, she was able to stay on her own path and the matter received closure - all the more so since she and Lilja virtually organised the last communal fire ritual held outside. They thus appropriated the traditionally conceived authoritative role, and the Blankas let it happen as part of the participants' process. It is peculiar that Lyydia changed her mind in the end:

Lyydia: But for me that, I, I don't remember how much we talked about this, but for me the fire ritual overall was not particularly important. Perhaps I couldn't get into it, or I have done so much of those kinds of things sometime a long time ago, so it was like, wait a minute, like. Bringing some, some wish or will, or something then putting it on the fire, that, that does not actually work for me. I do get fire as an element, maybe for me it is like a purifying element most of all and the warmth that it gives, there it is. Yeah, it does not really work for me (September 4, 2008).

Surprisingly, Lyydia states that the fire ritual was not important to her after all. I try to go through the practical matters of making the fire and the trouble of acquiring the firewood as part of the process (see Table 3). Lyydia sees that the events depicted in the earlier interview have been transformed into an artistic process of sorts. She refers to a paper on Fire ritual and agency I presented at a conference on the sociology of religion (Augusts 14, 2008), in which I characterised her activity as performing art. This interaction of the researcher and the participant is an interesting example of the complex interrelationships present in participatory anthropological research (see Raunola 2010).

The fire rituals of Assisi and the negotiations involved illustrate Lassander's concept of a trellis, a 'framework [that] is not particular about its 
boundaries [and] allows the harvesting of traditions from different cultures for symbols and narratives that suit the individual' (Lassander 2014, 155). Lyydia was able to stay on her path and negotiate her understanding of the fire ritual in a more artistic than religious way. The centre of calculations, the retreat in Assisi, and the fire rituals seemed to function for Lyydia not only as a place to negotiate but also as a test for her worldview. She agreed to take part in the process, but her negotiations shifted from the Lightprayer network to her own individual purposes.

\section{Conclusion}

During the retreat we exercised surrendering to the present moment and took the journey ever deeper to oneself - into who I am - and to feel and experience this moment in the silence of one's own, as the true being of oneself and also together as a group (Blog January 31, 2008).

Helena wrote this blog entry during the New Year retreat. To my mind this entry depicts the idea of the spiritual process both in the individual and as a group, and the whole meaning of Lightprayer. The function of Lightprayer and the retreats in particular was to create an environment that supported the spiritual process of the participants with various preparatory exercises and practices, such as 'I am' clauses and 'fire ritual', to get to know 'the true being' of oneself.

As a procedure in the anthropology of religion, ANT makes the human and non-human conditions of interpretation tangible, and it facilitates a flexible way of approaching the research material. As a result, the role of the practice of the spiritual process in Lightprayer is connected with interaction. The successful translations and shared protocol strengthen the connections and the status of Lightprayer. Once the participant accepts and takes part in Lightprayer according to its protocol, she receives personal knowledge that sustains her interest. The holistic and existential spiritual process is seen to involve the interplay of different levels of the individual. It seems that there are two levels of consciousness. The actors are 'higher self' and 'you'. The deep surface engages in a dialogue with the 'you' of the everyday cognitive activity and life situation to facilitate change and make it permanent - the work of becoming 'more whole'.

The metaphor 'life is a journey' is often equated to the spiritual process in Lightprayer. While the retreat entails momentarily retreating from 'life', the subsequent continuation of the journey suggests that the retreat is in 
fact an integral part of life with powerful repercussions beyond its temporal scope. Based on the analysis of the research material, the spiritual process is used to bring something new into the consciousness of the participants in addition to enhancing self-awareness. The metaphors of 'path' and 'journey' are used to illustrate personal views and emotions. The spiritual process in Lightprayer facilitates individual knowledge in each participant, Light agency, and experience of the relationship with oneself. The emphasis on the spiritual process may have intrigued and encouraged participants' 'trellises', or it may have formed a barrier between the Lightprayer and potential participants' 'moulds'. As an essential way of communicating, the spiritual process in any case performed a significant role in sustaining the Lightprayer actor network.

As a trellis-type formation, Lightprayer was very tolerant, transformable, and non-hierarchical. In centres of calculation such as the fire ritual the participants were able to actively take part in the organisation of the event. However, in certain matters the Blankas took the role of leading actors and the administrators of Lightprayer. The retreats and fire rituals were essential centres of calculation for enabling the spiritual process and hence the Lightprayer protocol that upheld the continuation of the activity of Lightprayer. Yet centres of calculation also enable the negotiation of individual worldviews.

In his research on paganism Lassander states that a definition of what constitutes religion is not necessary for actor-network theory (Lassander $2012,251)$. Instead, it is essential to examine the creative activity and interaction of the actors. In my case this means those involved in Lightprayer. Lightprayer is representative of new religious practices and is an antithesis of inertia and institutionalisation. There is no reason, however, to exclude the perspective or concepts of the study of religions in determining the religious aspects of the phenomenon. As this discussion demonstrates, a more fruitful approach is to assess the methodological gains of the interplay between different modes of research. This is what makes it anthropology of religion.

$$
* * *
$$

ILONA RAUNOLA is Doctoral Candidate in Cultural Anthropology at the University of Eastern Finland. Email: ilonaraunola@gmail.com 


\section{Research Material}

Retreats referred to in the article

May 21 - May 24, 2008 Assisi, Italy

September 27 - October 4, 2008 Airisto, Finland

December 27, 2008 - January 4, 2009 Schwangau, Germany

March 29 - April 1, 2009 New Valamo Orthodox Monastery in Heinävesi, Finland

\section{Interviews}

Research interviews, notes, photographs, and recordings are in the custody of the author.

Helena Blanka

December 31, 2008. Duration 51 mins, Schwangau.

Arja, September 28, 2008. Duration 38 mins.

Peppi, April 1, 2009. Duration 33 mins.

Leea, January 4, 2009. Duration 1 h 5 mins.

Saila, October 3, 2008. Duration 54 mins.

Lyydia, May 21, 2008. Duration 58 mins.

Lyydia, September 4, 2008. Duration 103 mins.

Notes May 21, 2008, Assisi: Picture of Mary on the mantelpiece \& the fire ritual description.

Notes May 22, 2008, Assisi: Fire ritual outside.

Notes January 1, 2009, Schwangau: Coconut on the fire.

Notes March 29, 2009, New Valamo: About the retreat.

Field recording September 28, 2008, Airisto: About the fire ritual (original in Finnish).

Field recording December 31, 2008, Schwangau: 'I am' clauses (original in Finnish).

\section{Websites}

LP Blog: Uuden vuoden retriittimatkalta - valo ja hiljaisuus alppien juurella, January 31, 2008. <http://valorukous.de/cgi-bin/weblog_basic>, accessed July 30, 2009.

Finnish original.

LP 3: Lightprayer English website: What is Lightprayer. July 9, 2007. <http:// www.free-planet.de/eng/wasistlichtgebet>, accessed March 9, 2012.

LP 4: Lightprayer English website: Lightprayer. July 27, 2011. < http://www. free-planet.de/eng/lichtgebet>, accessed March 9, 2012.

\section{Emails}

Email Helena Blanka. April 18, 2008. Assisi info. Finnish original.

Email Michael Blanka. January 20, 2015. Fire puja. Finnish original.

Email Leea. January 19, 2009. Necklace. Finnish original. 
Bibliography

Callon, Michel

1986 Some elements of a sociology of translation: domestication of the scallops and the fishermen of St Brieuc Bay. John Law (ed.), Power, action and belief: a new sociology of knowledge? 196-223. London: Routledge.

\section{Callon, Michel \& Latour, Bruno}

1981 Unscrewing the big Leviathan: how actors macro-structure the reality and how sociologists help them to do so. K. Knorr and A. Cicourel (Eds) Advances in Social Theory and Methodology, 277-303. London: Routledge.

\section{Dwivedi, Onkar P.}

2004 Hinduism. Frank A. Salamone (ed.), Encyclopedia of Religious Rites, Rituals and Festivals, 170-5. New York: Routledge.

Jöns, Heike

2011 Centre of calculation. John Agnew \& David Livingstone (eds), The Sage Handbook of Geographical Knowledge, 158-70. Sage.

\section{Lakoff, George \& Turner, Mark}

1989 More than Cool Reason. A Field Guide to Poetic Metaphor. Chicago: University of Chicago Press.

\section{Lassander, Mika}

2012 Grappling with Liquid Modernity: Investigating Post-Secular Religion. Peter Nynäs \& Mika Lassander \& Terhi Utriainen (eds), PostSecular Society, 239-67. New Jersey: Transaction Publishers.

2014 Post-Materialist Religion. Pagan Identities and Value Change in Modern Europe. Bloomsbury Academic.

\section{Lassander, Mika \& Ingman, Peik}

2012 Exploring the social without a separate domain for religion: on actornetwork theory and religion. Post-secular Religious Practices. Scripta Instituti Donneriani Aboensis, [S.1.], v. 24, p. 201-17. Available at: $<$ https://ojs.abo.fi/ojs/index.php/scripta/article/view/289>.

\section{Latour, Bruno}

1986 The powers of association. John Law (ed.) Power, Action and Belief. A New Sociology of Knowledge?, 261-77. London: Routledge.

1987 Science in Action: How to Follow Scientists and Engineers through Society. Cambridge: Harvard U.P.

2005 Reassembling the Social: An Introduction to Actor Network Theory. UK: Oxford University Press.

2006 Emme ole koskaan olleet moderneja. (Nous n'avons jamais été modernes: Essai d'anthropologie symétrique 1991.) Tampere: Vastapaino. 


\section{Law, John}

1992 Notes on the Theory of the Actor Network: Ordering, Strategy and Heterogeneity. Systems Practice, 5, 379- 93. Lancaster: Centre for Science Studies, Lancaster University.

\section{Melton, Gordon J.}

1990 New Age encyclopedia. A guide to the beliefs, concepts, terms, people and organizations that make up the new global movement toward spiritual development, health and healing, higher consciousness, and related subjects. Detroit, London: Gale Research Inc.

\section{Raunola, Ilona}

2010 Osallisuus ja dialoginen paikantuminen etnografisessa kenttätyössä. Jyrki Pöysä \& Helmi Järviluoma \& Sinikka Vakimo (Eds), Vaeltavat metodit, 285-314. Joensuu: Suomen Kansantietouden Tutkijain Seura, Kultaneito VIII.

2012 Uskon jäljet ja paikan mikropreesens. Seppo Knuuttila \& Helmi Järviluoma \& Anne Logrén \& Risto Turunen (Eds), Syrjäseudun idea. Kulttuurianalyysejä Ilomantsista, 147-63. Helsinki: Suomalaisen Kirjallisuuden Seura.

2017 Marian merkitys Valorukous-toiminnalle-uuden uskonnollisuuden toimijaverkkoteoreettinen tarkastelu. Uskonnontutkija 1/2017. 


\section{Appendix}

Table 1: The ANT vocabulary of Lightprayer

\begin{tabular}{|l|l|}
\hline Spiritual process & $\begin{array}{l}\text { Religious way of associating/pro- } \\
\text { tocol }\end{array}$ \\
\hline 'I am' clauses & Black Box \\
\hline Fire ritual & Centres of calculation \\
\hline Assisi case & Fire ritual as negotiation \\
\hline
\end{tabular}

Table 2: Actors of Lightprayer

\begin{tabular}{|l|l|}
\hline Light and Light agency & Quasi-object \\
\hline Lightprayer events & Centres of Calculation \\
\hline Retreats & Centres of Calculation \\
\hline Blankas & Mediator \\
\hline Participants & Mediator \\
\hline
\end{tabular}

Table 3: The Fire Ritual in Lyydia's network

\begin{tabular}{|l|l|}
\hline Blankas' firewood & Intermediaries \\
\hline Lyydia's and Lilja's branches & Mediators \\
\hline Fire ritual as spiritual process & $\begin{array}{l}\text { Centre of calculation and setting for } \\
\text { negotiations and spiritual process }\end{array}$ \\
\hline
\end{tabular}


Figure 1: The path is a common metaphor for spiritual progress. Destination, vehicle, and companion are optional components of a journey (Lakoff \& Turner 1989, 61). Lakoff points out the ubiquity of the path metaphor in the Judaeo-Christian cultural tradition. The most well-known biblical references are Psalm 23 and Matthew 7:13-14 (ibid. 1989, 9-10) (IR, December 31, 2008).
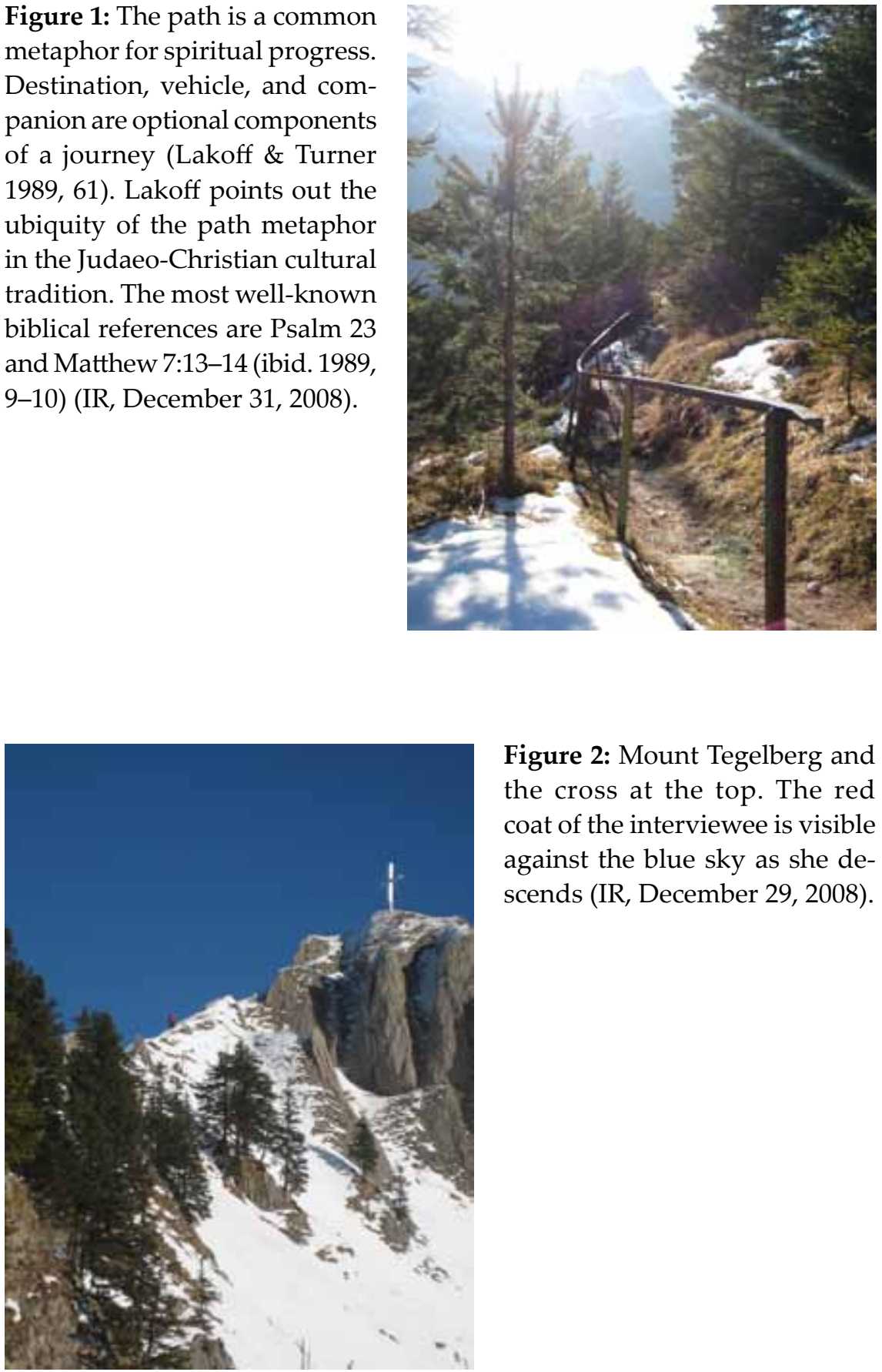

Figure 2: Mount Tegelberg and the cross at the top. The red coat of the interviewee is visible against the blue sky as she descends (IR, December 29, 2008). 
Figure 3: Fire ritual on New Year's Eve (IR, December 31, 2008).

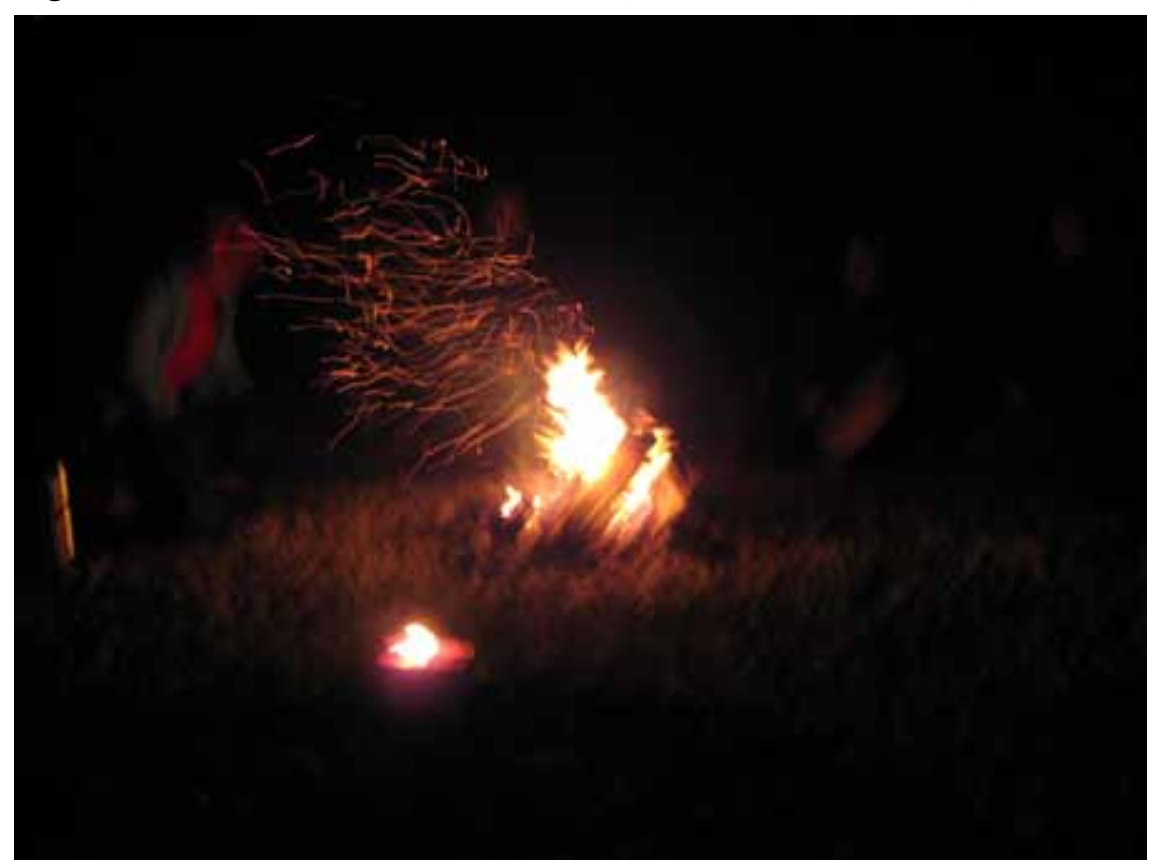

Figure 4: The fire ritual as a centre of calculation as negotiated by Michael Blanka.

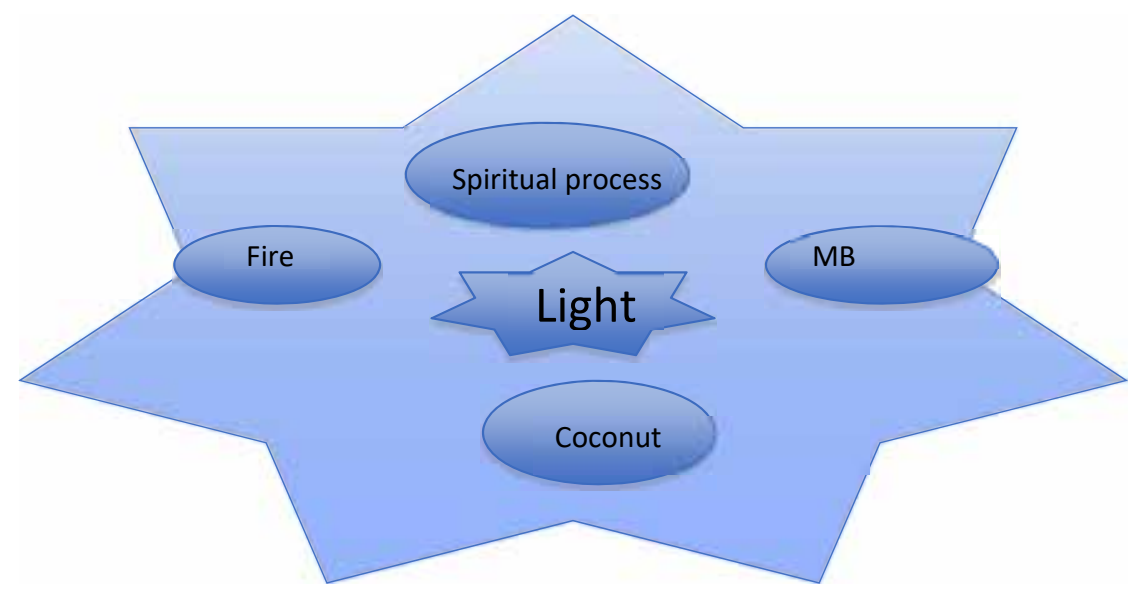


Figure 5: Helena and Michael Blanka prepare the fire ritual in Assisi. Helena chooses music from the laptop for the exercise. The picture of Mary has been placed on the mantelpiece and thus it is present during the fire ritual like an altarpiece (see Raunola 2017). In my field

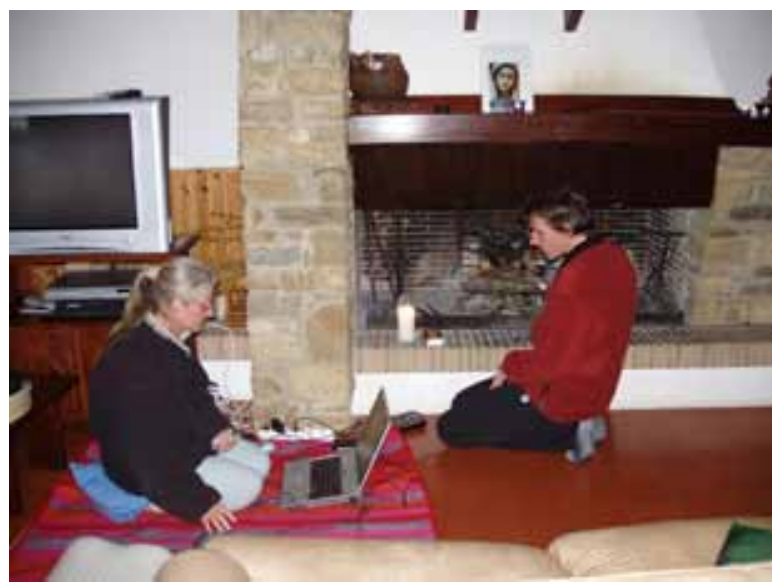
notes I recount how some of the participants had gone to particular trouble to get firewood for the ritual. One participant reports having seen Lyydia chopping firewood in the rain like one of the seven dwarves. Including the Blankas, there were seven of us at the retreat. The healer adds that the picture of Mary on the mantelpiece is akin to Snow White (Notes May 21, 2008). This is an illustrative comparison because much as Snow White guides the dwarves, Mary is present as an agent (IR, May 21, 2008).

Figure 6: Lyydia drying wood slats on the gas oven collected from the bin in the kitchen. Modern technology aids making the fire (IR, May 23, 2008).

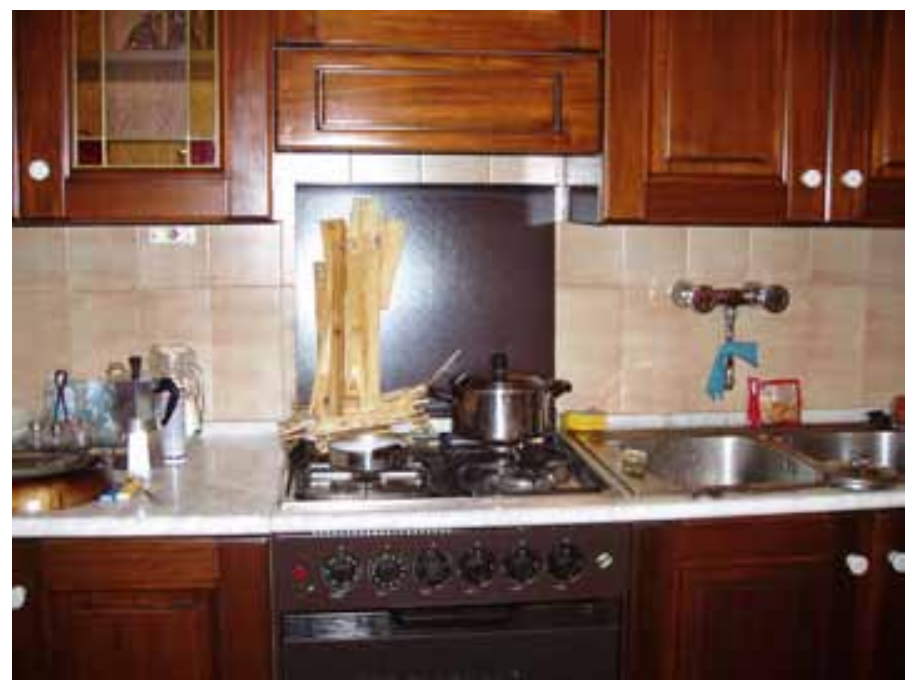


